\title{
Investigation of the energy efficiency of waste utilization technology, with considering the use of low-temperature separation of the resulting gas mixtures
}

\author{
Sergij Vambol', \\ Viola Vambol', \\ Vitaliy Sobyna ${ }^{2}$, \\ Volodymyr Koloskov ${ }^{1}$,

\section{Liubov Poberezhna ${ }^{3}$} \\ ${ }^{1}$ Department of Applied Mechanics \\ and Technologies of Environmental Protection, \\ National University of Civil Defence of Ukraine, \\ Chernyshevska St., 94, \\ 61023, Kharkiv, Ukraine \\ Email:vambol@nuczu.edu.ua; \\ koloskov@nuczu.edu.ua \\ ${ }^{2}$ Department of Logistics \\ and Technical Support of Rescue Operations, \\ National University of Civil Defence of Ukraine, \\ Chernyshevska St., 94, \\ 61023, Kharkiv, Ukraine \\ Email:violavambol@gmail.com; \\ vitaliysobyna@gmail.com \\ ${ }^{3}$ Department of Medical Informatics, \\ Medical and Biological Physics, \\ Ivano-Frankivsk National Medical University, \\ Halytska St., 2, \\ 76018, Ivano-Frankivsk, Ukraine \\ Email: lubomyrpoberezhny@gmail.com
}

Currently, there are existing technologies for high-temperature waste disposal, which use the resulting gas as fuel for recycling newly formed waste. However, the composition of waste is not constant, and contents of their components are different, thus, the need for fuel gas for burning is not stable. Therefore, such gas is constantly lost. Thus, the purpose of the article is to present the study results of the energy efficiency of high-temperature waste disposal technology, which includes low-temperature separation of the resulting gas mixtures, which allows accumulating fuel products. By means of numerical simulation an analysis of the functioning of energy-technological facility of separation of multicomponent hydrocarbon mixtures with the subsequent optimization of its parameters in order to improve its efficiency and decrease energy costs for waste gasification was performed. For this purpose, the classical approach and generally accepted thermodynamics relations were used, including the Peng-Robinson equation of state for the description of coefficients of heat-physical characteristics of working bodies. The complexity of calculation of multicomponent systems (with three and more components) does not allow application of the state diagrams. Thus, for the simulation of heat-physical characteristics the REFPROP program was employed. The energy efficiency of the proposed technology of energy resources production at waste utilization was shown. The amount of products obtained by the facility is equal to $5.242 \mathrm{~kg} /$ hour of the fuel product No. 1 with methane content of $99.98 \%$ and $54.76 \mathrm{~kg} /$ hour of the fuel product No. 2 with low quantity of methane. This confirms the economic efficiency of such technology of disposal.

Keywords: wastes, waste utilization, synthetic gas, energy characteristics 


\section{INTRODUCTION}

The development of new technologies and manufacturing processes is conditioned by the raise of requirements applied to materials and products made out of them. However, any manufacturing process is accompanied both by the harmful emission in the atmosphere [1-3] and waste generation $[4,5]$ leading to heavy metals accumulation in soil $[6,7]$. There are many modern technologies of utilization of different sorts of wastes [8-10] which allow to obtain raw materials for energy generation [11]. However, waste treatment in most cases is reduced down to waste dumping [12]. Since waste decomposition processes take place in limited periods on bounded territories, we observe high intensity of dangerous molecular compositions emission to the atmosphere [12] with the occurrence of unintentional fires $[13,14]$, thus, investigations on the assessment of civil protection units' readiness to actions during extreme situations are taken $[15,16]$. To avoid dumping of wastes not suitable for recycling, the preferences must be given to high-temperature ways of waste disposal such as incineration, pyrolysis and gasification, because high-temperature waste disposal with the aim of obtaining energy that can be used is a promising and relevant direction. It is important to understand the energy efficiency of high-temperature waste disposal.

In works [18-20] they have proven experimentally that waste utilization plasma technology application provides synthetic gas with calorie characteristics higher than those at traditional technology usage. In work [21] they have compared energy efficiency obtained at $1400 \mathrm{~K}$ temperature regime at waste utilization using processes of plasma and autothermal gasifications. There they have shown that with the existing methods of energy conversion the additional synthetic gas energy output obtained with plasma generators is not able to cover real costs of consumed electrical power. Vegetable and food wastes may be utilized by composting with special mineral additives [22], by means of decomposition in biogas equipment installations with subsequent thermal treatment of fermented residue in a pyrolysis furnace [23]. However, for unsorted solid municipal wastes such ways of utilization are technologically and economically inexpedi- ent. This is due to the fact that the composition of the waste is not manageable, and the amount of waste depends on seasonality and the number of people in the city (village, etc.). At the same time, energy consumption during the day is not constant. This means that under different conditions a different amount of energy is produced which must be used or accumulated.

High-temperature waste recycling methods application allows obtaining synthetic gas, the composition of which includes not only carbon monoxide $(\mathrm{CO})$ and hydrogen $\left(\mathrm{H}_{2}\right)$ but also such components as carbon dioxide $\left(\mathrm{CO}_{2}\right)$, nitrogen oxides $\left(\mathrm{NO}_{\mathrm{x}}\right)$, a small amount of methane $\left(\mathrm{CH}_{4}\right)$, ethylene $\left(\mathrm{C}_{2} \mathrm{H}_{4}\right)$, etc. The obtained low-calorie gas is used for direct combustion to produce heat both for domestic and electrical power generation needs. Due to the receipt of energy in the immediate vicinity of the place of use, this approach avoids losses during the transportation phase [17]. However, firstly, the resulting low-calorie gas is not enough to ensure the high-temperature disposal of waste, as mentioned above. Secondly, the receipt of waste and its composition is not constant, thus the need for fuel gas for burning is not constant. Also, the average daily and seasonal heat (energy) consumption is not constant. In that, when waste is not received for utilization, this gas is not used, does not accumulate and, therefore, is lost. Then it was proposed to use high-temperature waste disposal technology, which includes low-temperature separation of the resulting gas mixtures, which allows you to accumulate fuel products.

In works $[24,25]$ authors have proposed the technology of high-temperature waste utilization that allows to avoid the loss of heat and energy (which are occurring with uneven consumption) by creating fuel products suitable for storage and subsequent sale. This technology covers the following processes: thermochemical gasification; plasma post-combustion of produced gases; sharp cooling of gases; preliminary gas cleaning; gas methanation; final cleaning of produced gases; low-temperature separation of synthetic gas into fuel products. In the proposed waste utilization technology the reactor is made up of two chambers, one of which is the gasification reactor, and the other is the plasma reactor (Fig. 1). 


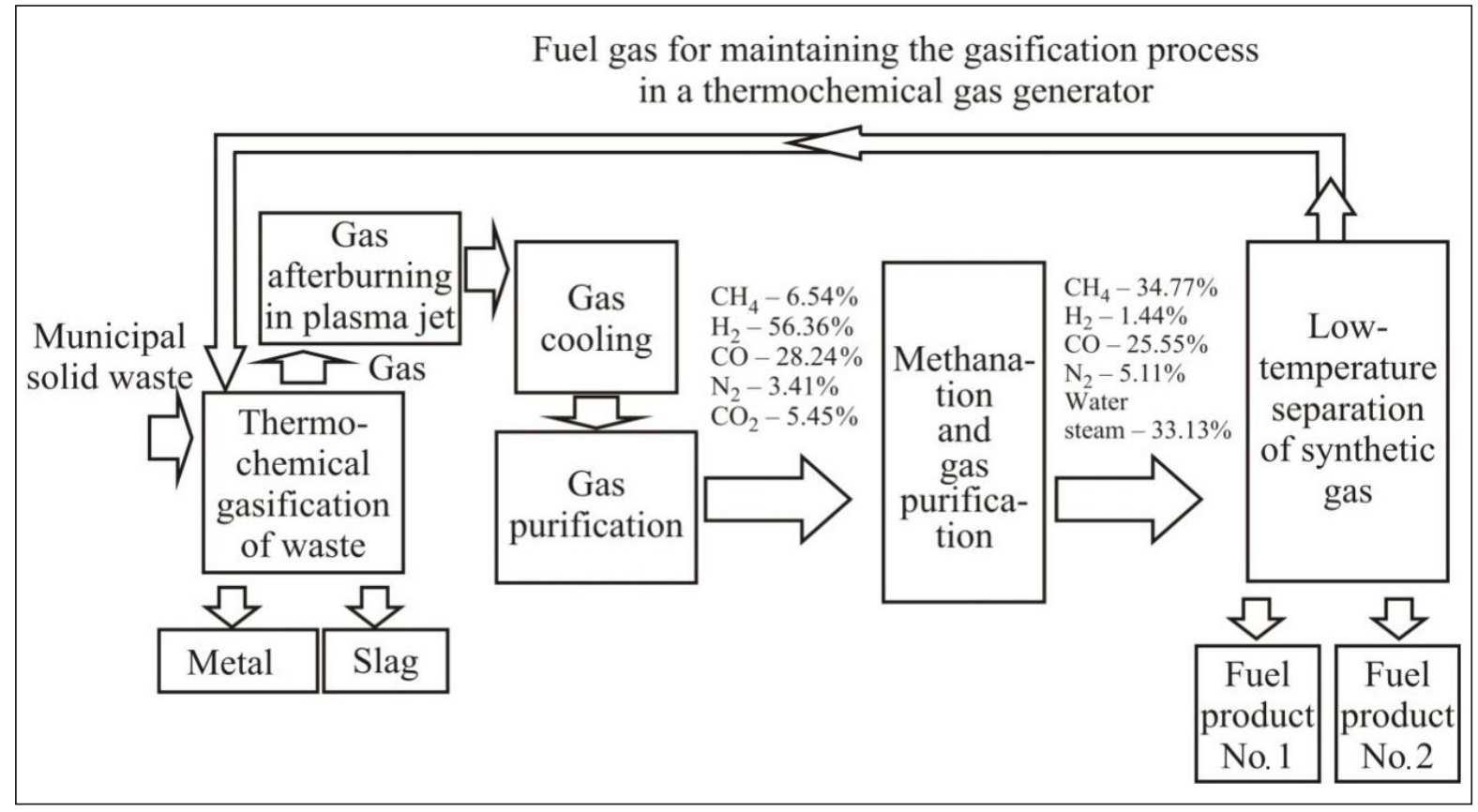

Fig. 1. Scheme of the sequence of technological stages of waste disposal

At first we carried out the process of high-temperature waste gasification and then the steamgas mixture was processed in the plasma jet. Such stepwise waste treatment reduces energy consumption, due to the fact that in a plasma reactor only the resulting gas, but not the whole mass of solid waste is processed. In the process, air was used as the main gasifying agent. As raw material, municipal solid waste was adopted, for which the average component composition was determined by statistical analysis [26]. After thermochemical gasification of waste, afterburning of exhaust gas in plasma [24], cooling of this gas [10], and necessary purification and enrichment of this gas with methane [25], the synthesis gas obtained enters for low-temperature separation to obtain fuel products of a given quality. As a result of the separation process, liquefied methane, liquefied methane-containing gas and fuel gas for heating, generating electricity or maintaining the gasification process in a thermochemical gas generator are formed. The basic scheme of the process of low-temperature separation of the gas mixture is shown in Fig. 2 [29].

After purification, the gas is dried in the block of adsorption drying (not shown in the scheme) and compressed in the C-1 compressor with a subsequent cooling in the air cooler $\mathrm{AC}$ to the ambient temperature. Next, the gas is divided into 3 streams and sent to the heat exchangers HE-1, HE-2, HE-3 for cooling backflow products. After combining all three streams, the gas enters the separator $\mathrm{S}$, where the liquid phase is separated (product No. 2). Then the pressure of the obtained liquid product in the pump P-1 rises to $22 \mathrm{MPa}$. The gaseous phase from separator $\mathrm{S}$ is cooled in the heat exchanger HE-4 and fed to the rectification column RC. From the condenser of the column in the upper part, gaseous product No. 1 is removed, which is a mixture of $\mathrm{CO}, \mathrm{H}_{2}$, and $\mathrm{N}_{2}$. This gas, passing through the expander part of the wave expander compressor (WEC), performs the expansion work, which is used to compress part of the source gas parallel to the $\mathrm{C}-1$ compressor. In the return flow, this gas passes through the HE-5, HE-4 and HE-1 heat exchangers, cooling successively the product No. 3 and the direct flow of the incoming gas. From the reboiler of the RC rectification column, product No. 3 enriched in methane is removed, which is compressed by a pump to a pressure of $22 \mathrm{MPa}$ and heated in the heat exchanger HE-3, after which it can be accumulated as a compressed gas.

The purpose of the article is to present study results on the energy efficiency of such waste utilization technology which includes low-temperature 


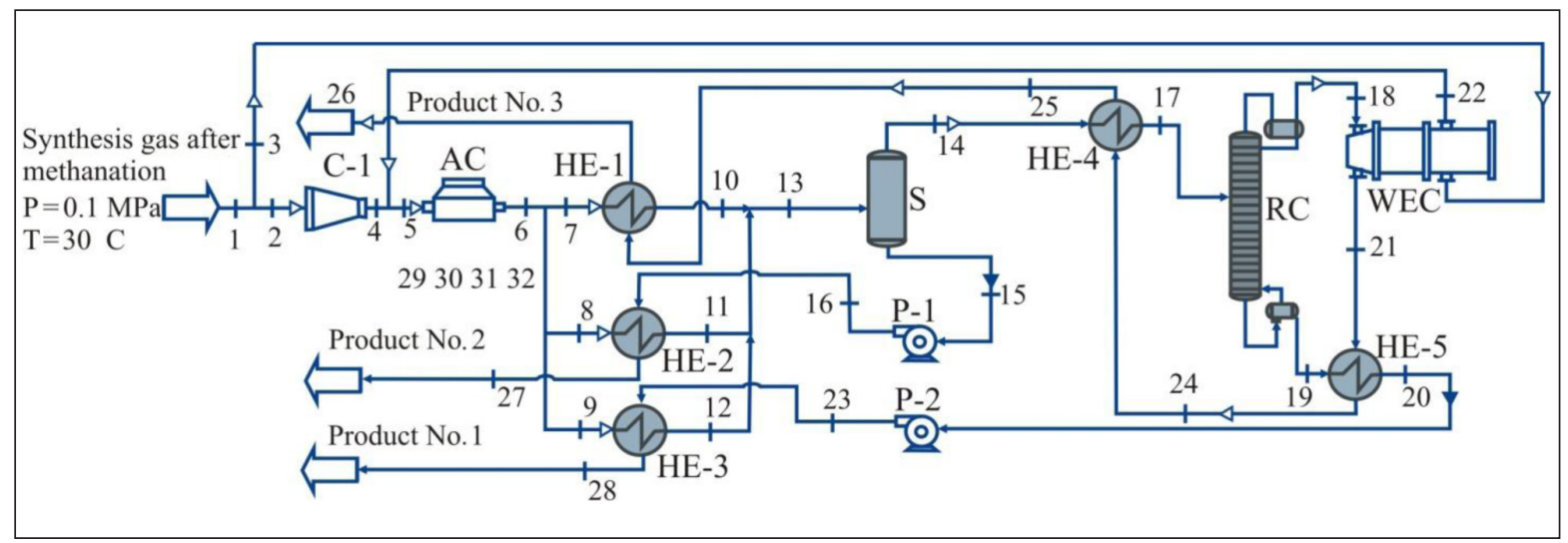

Fig. 2. The basic scheme of the process of low-temperature separation of the multicomponent hydrocarbon gas mixture [29]: (-1 - compressor; AC - air cooler; HE-1, HE-2, HE-3, HE-4, HE-5 - heat exchanger; P-1, P-2 - pump; S - separator; RC - rectification column; WEC - wave expander compressor

separation of the resulting gas mixtures, which allows to accumulate fuel products.

\section{MATERIALS AND METHODS}

By means of numerical simulation an analysis of the functioning of the energy-technological facility of separation of multicomponent hydrocarbon mixtures with the subsequent optimization of its parameters in order to improve its efficiency and decrease energy costs for waste gasification was accomplished.

For this purpose, the classical approach and generally accepted thermodynamics relations, including the Peng-Robinson equation of state for the description of coefficients of heat-physical characteristics of working bodies were used. The complexity of calculation of multicomponent systems (with three and more components) does not allow application of the state diagrams. Thus, for the simulation of heat-physical characteristics the REFPROP program was employed. To solve the system of non-linear equations the Newton-Raphson iteration method was used.

\section{RESULTS AND DISCUSSION}

In works [27, 28] authors have proposed the technique of calculation for each element of the low-temperature separation circuit and described initial parameters and assumptions.

The complexity of the processes taking place in the rectification column does not allow cre- ation of both a detailed and relatively simple mathematical model for rectification column parameters calculation. Thus, we use a black box model to describe rectification column functioning. We set multicomponent flow in the inlet of the rectification column with the known temperature $\mathrm{T}_{\mathrm{RC} I \mathrm{IN}}$, pressure $\mathrm{P}_{\mathrm{RC} \_\mathrm{IN}}$ and consumption $G_{\mathrm{IN}}$. With such initial data the set of subprograms designed for the calculation of coefficients of heat-physical characteristics of working bodies allows to obtain mass and molar composition of steam and liquid phases of the flow supplied in the inlet of the rectification column together with specific enthalpy of the flow. For the mathematical model of the rectification column we used the following assumptions [27]:

- the value of hydraulic losses in the rectification column is taken to be equal to zero;

- the heat exchange between structural elements of the rectification column is neglected;

- the pressure inside the column cube is taken to be higher than the one inside the condenser;

- the value of the rectification column feed pressure is taken to be in between the values mentioned above;

- the adjustment of the component composition of the products is made both by heat supply in the reboiler and heat removal in the condenser.

To describe the functioning of the rectification column we may use the following system of equations: 


$$
\begin{aligned}
& \mathrm{G}_{\mathrm{IN}}=\mathrm{G}_{\mathrm{L} \_ \text {OUT }}+\mathrm{G}_{\mathrm{V} \_ \text {OUT }}, \mathrm{G}_{\mathrm{IN}} \cdot \mathrm{i}_{\mathrm{m}}\left(\mathrm{P}_{\mathrm{RC} \_ \text {IN }}, \mathrm{T}_{\mathrm{RC} \_ \text {IN }}\right) \\
& =\mathrm{G}_{\mathrm{L}_{\text {_OUT }}} \cdot \mathrm{i}_{\mathrm{m}}\left(\mathrm{P}_{\mathrm{L}_{\text {_OUT }}}, \mathrm{T}_{\mathrm{L}_{\text {_OUT }}}\right)+\mathrm{Q}_{\mathrm{RB}} \\
& +\mathrm{G}_{\mathrm{V} \_ \text {OUT }} \cdot \mathrm{i}_{\mathrm{m}}\left(\mathrm{P}_{\mathrm{L}_{-} \text {OUT }}, \mathrm{T}_{\mathrm{V} \_ \text {OUT }}\right)-\mathrm{Q}_{\text {COND, }}
\end{aligned}
$$

where $g_{L_{\text {OOUT }}}, \mathrm{g}_{\mathrm{V}_{\text {_OUT }}}$ are consumption values in the rectification column outlet for single-phase liquid and gas products, correspondingly; $i_{m}$ is specific enthalpy of multicomponent mixture calculated for the given composition by means of the set of subprograms designed for the calculation of heat-physical characteristics coefficients; $\mathrm{T}_{\mathrm{L} \_ \text {OUT }}, \mathrm{P}_{\mathrm{L} \_ \text {OUT }}$ are temperature and pressure values, correspondingly, for liquid product in the reboiler outlet; $\mathrm{T}_{\mathrm{V}_{\mathrm{O} O U T}}, \mathrm{P}_{\mathrm{V}_{\mathrm{V} \text { OUT }}}$ are temperature and pressure values, correspondingly, for gas product in the condenser outlet; $Q_{R B}$ is heat supplied for the reboiler; $\mathrm{Q}_{\mathrm{COND}}$ is heat removed from the condenser.

Component compositions of the inlet and outlet products are connected with the following system of equations:

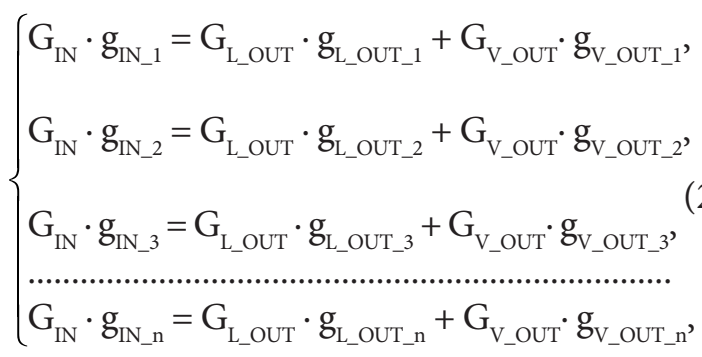

where $g_{\text {IN_i }}, g_{L_{L} \text { OUT } \_i}, g_{V_{-} \text {out_i }}$ are mass fractions of the i-th component in the rectification inlet, reboiler outlet and condenser outlet, correspondingly.

The calculation of rectification column parameters is made by the method of successive approximations [27]. Depending on the required value of mass content of the component the set of iterations is accomplished for given values of pressure inside the reboiler and condenser by means of the set of subprograms designed for the calculation of coefficients of heat-physical characteristics of working bodies. The initial value of mass content of steam and liquid phases is found using the column inlet parameters. Then for each iteration the system of equations (2) is recalculated for varying values of temperature inside the reboiler $\mathrm{T}_{\mathrm{L}_{-} \mathrm{OUT}}$ and condenser $\mathrm{T}_{\mathrm{V} \_ \text {OUT }}$ The calcula- tion process is completed when the previously set mass content value is obtained for certain component with the required accuracy. After that they calculate the values of heat supply in the reboiler $\mathrm{Q}_{\mathrm{RB}}$, heat removal from the condenser $\mathrm{Q}_{\mathrm{COND}}$, and mass consumption of liquid and gas phases.

Using the set of subprograms designed for the calculation of coefficients of heat-physical characteristics of working bodies based on the Peng-Robinson equation of state [27] we calculate mass composition of liquid and gas phases:

$$
\begin{aligned}
& \mathrm{g}_{\mathrm{CO}_{-} 14^{1}}, \mathrm{~g}_{\mathrm{H}_{2 \_} 14^{1}}, \mathrm{~g}_{\mathrm{CO}_{4} \_14^{\prime}} \mathrm{g}_{\mathrm{N}_{2-1} 14} \\
& =\mathrm{f}_{6}\left(\mathrm{P}_{13}, \mathrm{~T}_{13}, \mathrm{~g}_{\mathrm{CO}_{-} 13}, \mathrm{~g}_{\mathrm{H}_{2} \_13}, \mathrm{~g}_{\mathrm{CH}_{4} \_13}, \mathrm{~g}_{\mathrm{N}_{2}-13}\right) \text {, } \\
& \mathrm{g}_{\mathrm{CO}_{-} 15}, \mathrm{~g}_{\mathrm{H}_{2}-15}, \mathrm{~g}_{\mathrm{CO}_{4} \_15}, \mathrm{~g}_{\mathrm{N}^{2} \_15} \\
& =\mathrm{f}_{6}\left(\mathrm{P}_{13}, \mathrm{~T}_{13}, \mathrm{~g}_{\mathrm{CO}_{-} 13}, \mathrm{~g}_{\mathrm{H}_{2}-13}, \mathrm{~g}_{\mathrm{CH}_{4}-13}, \mathrm{~g}_{\mathrm{N}_{2}-13}\right) \text {. }
\end{aligned}
$$

According to the results of calculations, three flows of energy resources may be obtained. The flows with a high mass content of methane of $91.53 \%$ (control section 28, Fig. 2) and 83.48\% (control section 27, Fig. 2) are compressed products and they may be used both as motor fuel (analogue of compressed automobile natural gas). The gas flow obtained in control section 26 (Fig. 2) is suitable for maintaining the process of gasification of waste (Table 1).

It is obvious that the proposed scheme of the low-temperature separation of multicomponent hydrocarbon mixtures satisfies conditions of the task. Yet a more efficient alternative may be found. For example, according to the results in the condenser of the rectification column RC it is required to use the refrigerant with the temperature less than $-1820176 \mathrm{C}$ allowing to remove heat power of $2.836 \mathrm{~kW}$. Liquid nitrogen meets requirements on temperature level. At normal conditions the value of hidden evaporation heat is equal to $\Psi=197.6 \mathrm{~kJ} /(\mathrm{kg} \cdot \mathrm{K})$, then refrigerant consumption is equal to $51.7 \mathrm{~kg} / \mathrm{hour}$. Liquid nitrogen usage can be excluded if the condenser is not included in the composition of the column. Then the costs value will decrease. However, in such case, as it may be proven with the numerical simulation results, there will be no opportunity to separate the whole amount of methane from the "top" flow. The scheme of such alternative 
Investigation of the energy efficiency of waste utilization technology, with considering the use of low-temperature... 191

Table 1. Mass fraction of the components of the hydrocarbon gas mixture in the control sections

\begin{tabular}{|c|c|c|c|c|c|c|c|}
\hline \multirow{2}{*}{$\begin{array}{l}\text { Control } \\
\text { section }\end{array}$} & \multirow{2}{*}{ Pressure, MPa } & \multirow{2}{*}{ Temperature, ${ }^{\circ} \mathrm{C}$} & \multirow{2}{*}{$\begin{array}{c}\text { Consumption, } \\
\mathrm{kg} / \mathrm{h}\end{array}$} & \multicolumn{4}{|c|}{ Mass composition of the product } \\
\hline & & & & $\mathrm{CH}_{4}$ & $\mathrm{H}_{2}$ & $\mathrm{CO}$ & $\mathbf{N}_{2}$ \\
\hline 1 & 0.1 & 30 & 60.0 & 0.3756 & 0.0196 & 0.4287 & 0.1761 \\
\hline 2 & 0.1 & 30 & 54.0 & 0.3756 & 0.0196 & 0.4287 & 0.1761 \\
\hline 3 & 0.1 & 30 & 6.0 & 0.3756 & 0.0196 & 0.4287 & 0.1761 \\
\hline 4 & 0.6 & 250.7 & 54.0 & 0.3756 & 0.0196 & 0.4287 & 0.1761 \\
\hline 5 & 0.6 & 250.7 & 60.0 & 0.3756 & 0.0196 & 0.4287 & 0.1761 \\
\hline 6 & 0.6 & 30 & 60.0 & 0.3756 & 0.0196 & 0.4287 & 0.1761 \\
\hline 7 & 0.6 & 30 & 16.8 & 0.3756 & 0.0196 & 0.4287 & 0.1761 \\
\hline 8 & 0.6 & 30 & 9.0 & 0.3756 & 0.0196 & 0.4287 & 0.1761 \\
\hline 9 & 0.6 & 30 & 34.2 & 0.3756 & 0.0196 & 0.4287 & 0.1761 \\
\hline 10 & 0.6 & -168.1 & 16.8 & 0.3756 & 0.0196 & 0.4287 & 0.1761 \\
\hline 11 & 0.6 & -130.6 & 9.0 & 0.3756 & 0.0196 & 0.4287 & 0.1761 \\
\hline 12 & 0.6 & -119.7 & 34.2 & 0.3756 & 0.0196 & 0.4287 & 0.1761 \\
\hline 13 & 0.6 & -150.4 & 60.0 & 0.3756 & 0.0196 & 0.4287 & 0.1761 \\
\hline 14 & 0.6 & -150.4 & 55.21 & 0.3358 & 0.0212 & 0.4553 & 0.1877 \\
\hline 15 & 0.6 & -150.4 & 4.79 & 0.8347 & 0 & 0.1228 & 0.0424 \\
\hline 16 & 22.0 & -135.6 & 4.79 & 0.8347 & 0 & 0.1228 & 0.0424 \\
\hline 17 & 0.6 & -151.8 & 55.21 & 0.3358 & 0.0212 & 0.4553 & 0.1877 \\
\hline 18 & 0.596 & -177.5 & 35.04 & 0.0023 & 0.0335 & 0.6782 & 0.2860 \\
\hline 19 & 0.6 & -140.7 & 20.17 & 0.9152 & 0 & 0.0679 & 0.0168 \\
\hline 20 & 0.6 & -140.8 & 20.17 & 0.9152 & 0 & 0.0679 & 0.0168 \\
\hline 21 & 0.115 & -194.6 & 35.04 & 0.0023 & 0.0335 & 0.6782 & 0.2860 \\
\hline 22 & 0.6 & 250.7 & 6.0 & 0.3756 & 0.0196 & 0.4287 & 0.1761 \\
\hline 23 & 22.0 & -124.7 & 20.17 & 0.9152 & 0 & 0.0679 & 0.0168 \\
\hline 24 & 0.115 & -194.6 & 35.04 & 0.0023 & 0.0335 & 0.6782 & 0.2860 \\
\hline 25 & 0.115 & -172.8 & 35.04 & 0.0023 & 0.0335 & 0.6782 & 0.2860 \\
\hline 26 & 0.115 & 11.00 & 35.04 & 0.0023 & 0.0335 & 0.6782 & 0.2860 \\
\hline 27 & 22.0 & 17.16 & 4.79 & 0.8348 & 0 & 0.1228 & 0.0424 \\
\hline 28 & 22.0 & -3.17 & 20.17 & 0.9153 & 0 & 0.0679 & 0.0168 \\
\hline
\end{tabular}

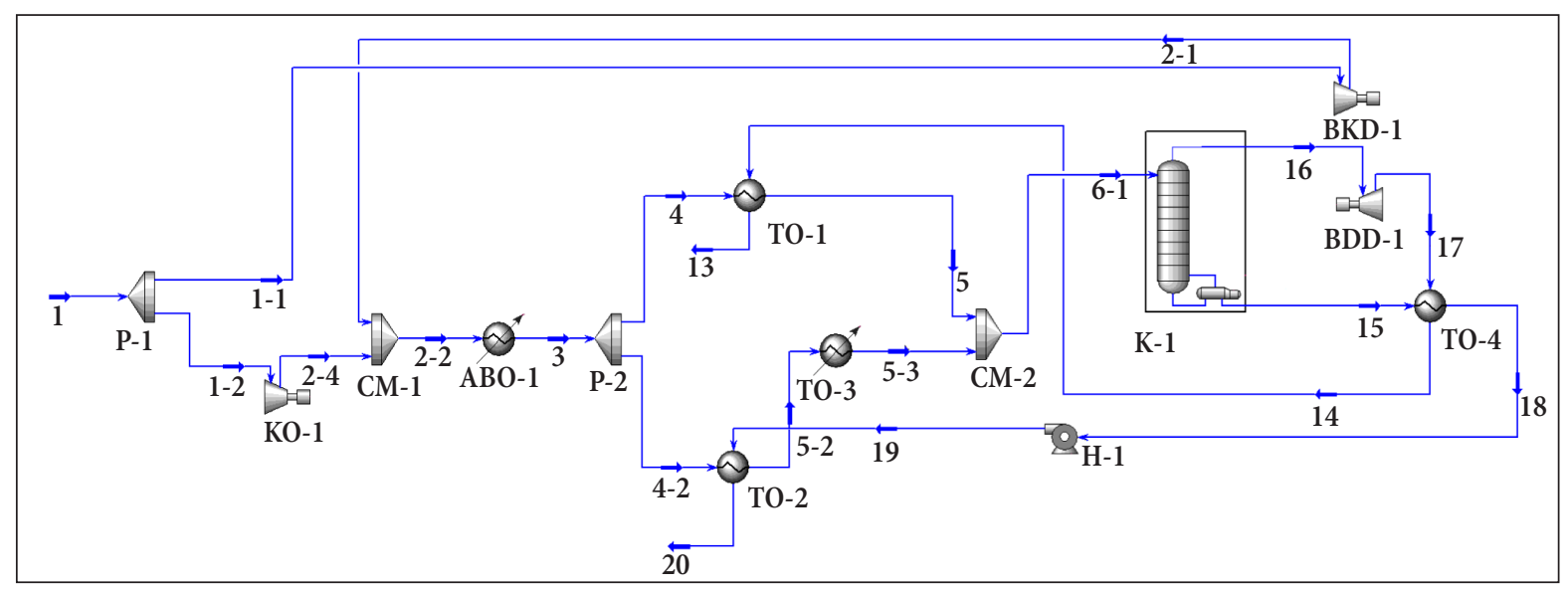

Fig. 3. The scheme of low-temperature gas separation with the rectification column without a condenser 
of the low-temperature gas separation facility is shown in Fig. 3.

The amount of products obtained by the facility is equal to $5.242 \mathrm{~kg} /$ hour of the product No. 1 with methane content of $99.9 \%\left(\mathrm{CH}_{4}-99.9 \%\right.$, $\left.\mathrm{H}_{2}-0 \%, \mathrm{CO}-0.09 \%, \mathrm{~N}_{2}-0.01 \%\right)$ and $54.76 \mathrm{~kg} /$ hour of the product No. 2 with a low content of methane $\left(\mathrm{CH}_{4}-36.49 \%, \mathrm{H}_{2}-19.69 \%\right.$, $\left.\mathrm{CO}-31.06 \%, \mathrm{~N}_{2}-12.76 \%\right)$. If the scheme shown in Fig. 3 is implemented, the product will be released as a pure methane in compressed shape.

To accomplish energy assessment of the expedience of application of the low-temper- ature gas separation technology realized on the scheme with the rectification column without a condenser, comparative calculations for approximate productivity of municipal solid wastes recycling equal to 1.6 ton/day $(66.8 \mathrm{~kg} /$ hour, 529 ton/year) were made.

During realization of the proposed scheme the following products may be obtained: liquefied or gaseous methane under pressure equal to $25 \mathrm{MPa}-16.8 \mathrm{~kg} /$ day; fuel gas $-37.1 \mathrm{~kg} /$ hour; slag $-6.68 \mathrm{~kg} / \mathrm{hour}$.

A lower heating value of the fuel is an additive function defined as the sum of heating values of combustive components of fuel [27]. The values

Table 2. Evaluation of generated energy amount

\begin{tabular}{|c|c|}
\hline Parameters & Values \\
\hline Raw materials amount, kg/h & 66.80 \\
\hline Raw materials amount, ton/day & 1.60 \\
\hline Raw materials amount, ton/year & 529 \\
\hline \multicolumn{2}{|l|}{ Products amount per hour: } \\
\hline methane liquefied, $\mathrm{kg} / \mathrm{hour}$ & 16.80 \\
\hline fuel gas for heating, kg/hour & 37.10 \\
\hline slag, kg/hour & 6.68 \\
\hline \multicolumn{2}{|l|}{ Products amount per year (330 operative days): } \\
\hline methane liquefied, ton/year & 133.06 \\
\hline fuel gas for heating, ton/year & 293.83 \\
\hline Lower heating value of syngas, $\mathrm{kJ} / \mathrm{m}^{3}$ & 9467 \\
\hline Density, kg/m³ & 0.827 \\
\hline Lower heating value of syngas, $\mathrm{kJ} / \mathrm{kg}$ & 7829 \\
\hline Lower heating value of syngas, $\mathrm{kWh} / \mathrm{kg}$ & 2.17 \\
\hline Steam generator efficiency & 0.9 \\
\hline Heat energy, kWh & 72.62 \\
\hline Heat energy, kWh/year & 575123 \\
\hline Steam cycle efficiency & 0.32 \\
\hline Electrical energy in steam cycle, kWh/year & 184039 \\
\hline Gas turbine cycle efficiency & 0.45 \\
\hline Electrical energy in gas-turbine cycle, kWh/year & 258805 \\
\hline Slag, ton/year & 52.91 \\
\hline \multicolumn{2}{|l|}{ Products amount, ton per 1 ton of raw materials: } \\
\hline methane liquefied, ton per 1 ton & 0.25 \\
\hline fuel gas for heating, ton per 1 ton & 0.44 \\
\hline Heat energy, kWh/ton of raw materials & 1087 \\
\hline Electrical energy in steam cycle, kWh/ton of raw materials & 347.86 \\
\hline Electrical energy in gas-turbine cycle, kWh/ton of raw materials & 489.18 \\
\hline Slag, ton per 1 ton of raw materials & 0.10 \\
\hline
\end{tabular}


of parameters on the amount of generated energy are shown in Table 2.

Calculation results show that a lower heating value of produced gas is equal to $9467 \mathrm{~kJ} / \mathrm{m}^{3}$.

Fuel gas is directed into the steam generator or combustion chamber, then it is sent to the electrical energy generation turbine. Two ways of electricity production were considered: the first one for the steam cycle, the second one for the direct fuel combustion using a gas turbine. When the steam cycle is applied, it is considered that the steam generator efficiency is equal to $90 \%$, and steam cycle efficiency is equal to $32 \%$. The obtained amount of electrical energy is equal to:

$$
\mathrm{E}_{\mathrm{El.En.}}=\mathrm{q}_{\mathrm{FG}} \cdot \eta_{\mathrm{SF}} \cdot \eta_{\mathrm{SC}}
$$

where $\mathrm{q}_{\mathrm{FG}}$ is lower heating value of the fuel gas; $\eta_{\mathrm{SG}}$ is steam generator efficiency; $\eta_{\mathrm{SC}}$ is steam cycle efficiency.

When electrical energy is generated at the gas-turbine equipment, it is considered that heat energy losses are equal to $10 \%$, and gas-turbine equipment efficiency is equal to $50 \%$.

The obtained amount of electrical energy is equal to:

$$
\mathrm{E}_{\mathrm{El} \text {.En. }}=0.9 \cdot \mathrm{q}_{\mathrm{FG}} \cdot \eta_{\mathrm{GTC}}
$$

where $\eta_{\text {GTC }}$ is gas-turbine cycle efficiency.

Calculation results prove that the amount of electrical energy generated on proposed technology using 1 ton of raw materials is equal to $348 \mathrm{kWh}$ and $489 \mathrm{kWh}$ in steam and gas-turbine cycles, correspondingly.

\section{CONCLUSIONS}

1. The results of numerical simulations show that implementation of the facility of low-temperature separation of multicomponent hydrocarbon mixtures provides formation of flows of energy resources. The amount of products obtained by the facility is equal to $5.242 \mathrm{~kg} / \mathrm{h}$ of the product No. 1 with methane content of $99.98 \%$ and $54.76 \mathrm{~kg} / \mathrm{h}$ of the product No. 2 with low content of methane.

2. The use of waste utilization technology, which includes the stage of low-temperature separation of the resulting gas mixtures, allows to compensate daily and seasonal irregularities of electrical energy and heat consumption by means of manufacturing fuel products suitable for storage and subsequent realization.

Received 8 October 2018 Accepted 7 November 2018

\section{References}

1. Kondratenko O. M., Vambol S. O., Strokov O. P., Avramenko A. M. Mathematical model of the efficiency of diesel particulate matter filter. Naukovyi Visnyk Natsionalnoho Hirnychoho Universytetu. 2015. Vol. 6. No. 150. P. 55-61.

2. Biliaiev M. M., Rusakova T. I., Kolesnik V. Ye., Pavlichenko A. V. The predicted level of atmospheric air pollution in the city area affected by highways. Naukovyi Visnyk Natsionalnoho Hirnychoho Universytetu. 2016. No. 1. P. 90-97.

3. Vambol S., Vambol V., Kondratenko O., Suchikova Y., Hurenko O. Assessment of improvement of ecological safety of power plants by arranging the system of pollutant neutralization. Eastern-European Journal of Enterprise Technologies. 2017. Vol. 1. No. 10(7). P. 63-73.

4. Krusir G. V. Acid-base and ionexchange properties of dietary fibers. Prikladnaia biokhimiia $i$ mikrobiologiia. 1992. Vol. 28. No. 2. P. 297-303.

5. Rafiee A., Gordi E., Lu W., Miyata Y., Shabani H., Mortezazadeh S., Hoseini M. The impact of various festivals and events on recycling potential of municipal solid waste in Tehran, Iran. Journal of Cleaner Production. 2018. No. 183. P. 77-86.

6. Voitiuk Y. Y., Kuraieva I. V., Kroik A. A., Pavlychenko A. V. Ecological and geochemical assessment of the soil contamination levels in the areas of metallurgical enterprises operation. Scientific Bulletin of National Mining Universit. 2014. No. 4. P. 45-51.

7. Alimardan M., Ziarati P., Moghadam R. J. Adsorption of heavy metal ions from contaminated soil by B. integerrima barberry. Biomedical and Pharmacology Journal. Vol. 9. No. 1. P. 169-175, 2016. DOI: $10.13005 / \mathrm{bpj} / 924$.

8. Shmandiy V. M., Nikiforov V. V., Alferov V. P., Kharlamova E. V., Pronin V. A. Use of blue-green algae for biogas production. Gigiena $i$ sanitariia. 2010. No. 6. P. 35-41. 
9. Biletska V. A., Yatsechko N. Ye, Demura V. I., Pavlychenko A. V. Application of natural sorbents for waste detoxication. Scientific Bulletin of National Mining University. 2014. No. 6. P. 120-125.

10. Vambol V. Numerical integration of the process of cooling gas formed by thermal recycling of waste. Eastern-European Journal of Enterprise Technologies. 2016. Vol. 6. No. 8(84). P. 48-53.

11. Liutak O., Savosh L., Baula O. Features of the use of alternative energy sources in Ukraine and the world. Baltic Journal of Economic Studies. 2017. Vol. 3. No. 4. P. 151-156.

12. Vambol S., Vambol V., Bogdanov I., Suchikova Y., Rashkevich N. Research of the influence of decomposition of wastes of polymers with nano inclusions on the atmosphere. Eastern-European Journal of Enterprise Technologies. 2017. Vol. 6. No. 10(90). P. 57-64.

13. Vambol S. O., Vambol V. V., Koloskov V. Yu., Derkach Yu. F. Prognozuvannja rivnja bezpeky nesankcionovanogo smittjezvalyshha z vykorystannjam imitacijnogo modeljuvannja. Ekologichna bezpeka. 2016. Vol. 2. No. 22. P. 51-58.

14. Vambol S. O., Koloskov V. Yu., Derkach Yu. F. Ocinjuvannja ekologichnogo stanu terytorij, pryleglyh do misc' zberigannja vidhodiv, na osnovi kryteriju ekologichnogo rezervu. Tehnogenno-ekologichna bezpeka. 2017. No. 2. P. 67-72.

15. Tiutiunyk V. V., Ivanets H. V., Tolkunov I. A., Stetsyuk E. I. System approach for readiness assessment units of civil defense to actions at emergency situations. Naukovyi Visnyk Natsionalnoho Hirnychoho Universytetu. 2018. No. 1. P. 99-105.

16. Dubinin D., Korytchenko K., Lisnyak A., Hrytsyna I., Trigub V. Improving the installation for fire extinguishing with finelydispersed water. Eastern-European Journal of Enterprise Technologies. 2018. Vol. 2. No. 10(92). P. 38-43.

17. Maruschak P., Bishchak R., Prentkovskis O., Poberezhnyi L., Danyliuk I., Garbinčius G. Peculiarities of the static and dynamic failure mechanism of long-term exploited gas pipeline steel. Advances in Mechanical Engineering. 2016. Vol. 8. No. 4. P. 1-8.

18. Zhang Q., Dor L., Yang W., Blasiak W. Properties and optimizing of a plasma gasification \& melting process of municipal solid waste. Proceedings of International Conference of Thermal Treatment Technology \& Hazardous Waste Combustors
(IT3/HWC), San Francisco, California, USA, 2010. P. 296-316.

19. Lemmens B., Elslander H., Vanderreydt I., Peys K., Diels L., Oosterlinck M., Joos M. Assessment of plasma gasification of high caloric waste streams. Waste Management. 2017. Vol. 27. No. 11. P. 1562-1569.

20. Falcucci G., Jannelli E., Minutillo M., Ubertini S., Han J., Yoon S. P., Nam S. W. Integrated numerical and experimental study of a MCFC-plasma gasifier energy system. Applied Energy. 2012. Vol. 97. P. 734-742.

21. Batenin V. M., Kovbasjuk V. I., Kretova L. G., Medvedev Ju. V. Termicheskaja utilizacija tverdyh bytovyh othodov. Teplojenergetika. 2011. No. 3. P. 62-66.

22. Sagdeeva O., Krusir G., Tsykalo A., Shpyrко T., Leuenberge $\mathrm{H}$. Composting of organic waste with the use of mineral additives. Harchova nauka ta tehnologija. 2018. Vol. 12. No. 1. P. 45-52.

23. Maksimov M. M., Davydov V. O., Krusir G. V., Maksimova O. B. Increasing of process energy efficiency of biogas plants production processing. Proceedings of Odessa Polytechnic University. 2017. Vol. 3. No. 53. P. 43-53.

24. Nechiporuk N. V., Kobrin V. N., Vambol V. V. Utilizacija letatel'nyh apparatov: monografija. Kharkiv, KhAI. 2014. P. 303.

25. Chubenko A. S., Kobrin V. N., Vambol V. V. Jekologicheski chistaja utilizacija othodov zhiznedejatel'nosti. Otkrytye informacionnye i komp'juternye integrirovannye tehnologii: sb. nauch. tr. Nac. ajerokosm. un-ta im. N. E. Zhukovskogo "KhAI". 2014. Vol. 62. P. 98-102.

26. Mikhaylenko V. P., Alekseyevets I. L., Denafas G., Shmarin S. L., Luchko I. A. Osobennosti obrazovaniya tverdykh bytovykh otkhodov $v$ Ukraine. Bytovyye otkhody. WasteECo. 2012. Available: https://waste.ua/eco/2012/municipal-waste/ ukraine/.

27. Vambol S., Shakhov Y., Vambol V., Petukhov I. A mathematical description of the separation of gas mixtures generated by the thermal utilization of waste. Eastern-European Journal of Enterprise Technologies. 2016. Vol. 1. No. 2(79). P. 35-41.

28. Vambol S. A., Shakhov Yu. V., Vambol V. V., Petukhov I. I. Mathematical model of calculation of the separator and the compressor unit of separation of gas mixtures in waste management. 
Technology Audit and Production Reserves. 2016. Vol. 1. No. 1(27). P. 50-53.

29. Vambol S. A., Shakhov Yu. V., Vambol V. V., Petukhov I. I. Matematicheskoye opisaniye protsessov v ustanovke razdeleniya gazovykh smesey pri utilizatsii otkhodov. Technology Audit and Production Reserves. 2016. Vol. 3. No. 3(29). P. 62-67.

Sergij Vambol, Viola Vambol, Vitaliy Sobyna, Volodymyr Koloskov, Liubov Poberezhna

ATLIEKỤ UTILIZAVIMO TECHNOLOGIJOS, PAPILDOMAI NAUDOJANČIOS

ŽEMATEMPERATŪRINİ SUSIDARIUSIŲ DUJŲ ATSKYRIMĄ, ENERGETINIO EFEKTYVUMO TYRIMAS

Santrauka

Pasaulyje egzistuoja aukštos temperatūros atliekų utilizavimo technologijos, kurios naudoja gautas generatorines dujas kaip kurą naujai ịvestoms atliekoms perdirbti / neutralizuoti. Tačiau atliekų struktūra nèra pastovi, tad susidariusių generatorinių dujų sudètis ir kokybè taip pat labai skiriasi. Gali būti prarandama dalis generatorinių dujų, kurios būtų panaudotos procese. Straipsnio tikslas yra pateikti aukštos tem- peratūros atliekų utilizavimo technologijos energijos vartojimo efektyvumo tyrimą, apimanti dujiniu mišinių atskyrimą žemoje temperatūroje (žemos temperatūros separaciją). Modeliuojant buvo atlikta daugiakomponentinių angliavandenilių mišinių atskyrimo technologinio įrenginio veikimo analizè ir tolesnè jo parametrų optimizacija, siekiant pagerinti jo efektyvumą ir sumažinti energijos sąnaudas, susijusias su dujinimo atliekomis. Šiam tikslui buvo naudojami klasikiniai termodinamikos modeliai ir dèsniai, įskaitant Peng-Robinsono būsenos lygtị, apibūdinančią šiluminių-fizikinių charakteristikų koeficientus. Daugiakomponentinių sistemų (su trimis ir daugiau komponentais) skaičiavimo sudetingumas neleidžia taikyti būsenos diagramų. Taigi fizikinių charakteristikų modeliavimui buvo naudojama REFPROP programa. Iš modeliavimo rezultatų matyti tokios utilizavimo technologijos ekonominis efektyvumas: gautu produktų kiekis yra 5,242 kg/val. kuro produkte Nr. 1, kurio metano kiekis yra 99,98 \% ir 54,76 kg/h, ir kuro produkte Nr. 2, kuriame yra mažas metano kiekis.

Raktažodžiai: atliekos, atliekų panaudojimas, generatorinès (sintetinès) dujos, energijos charakteristikos 